\title{
New analysis of variability of cheek teeth in Eurasian badgers (Carnivora, Mustelidae, Meles)
}

\section{Gennady F. Baryshnikov, Andrey Yu. Puzachenko \& Alexei V. Abramov}

\begin{abstract}
Variation of cheek teeth in 661 specimens of Eurasian badgers was studied. Geographic distribution of tooth size and morphotypical characters was analyzed. Presence of two groups of badgers ("western" and "eastern") regarded as allopatric species Meles meles and M. anakuma is confirmed. The small badger from south-western Norway is placed in a new subspecies $M$. meles milleri ssp. nov. Mosaic pattern of distribution of dental characters and different directions of specialization of cheek teeth in Meles meles and M. anakuma are established. It is assumed on the basis of paleontological material that both species originated from the Late Pliocene $M$. thorali, their divergence began in the early Pleistocene, and separation on species level occurred in the Middle Pleistocene.
\end{abstract}

KEY WORDS. Meles, teeth, geographical variability, systematics, evolution, Eurasia.

Gennady F. Baryshnikov [g_baryshnikov@mail.ru], Zoological Institute, Russian Academy of Sciences, Universitetskaya nab. 1, Saint Petersburg 199034, Russia; Andrey Yu. Puzachenko [puzak@newmail.ru], Institute of Geography, Russian Academy of Sciences, Staromonetnyi per. 22, Moscow 109017, Russia; Alexei V. Abramov [aav@AA2510.spb.edu], Zoological Institute, Russian Academy of Sciences, Universitetskaya nab. 1, Saint Petersburg 199034, Russia.

\section{Новый анализ изменчивости щечных зубов барсуков рода Meles (Carnivora, Mustelidae)}

\section{Г.Ф. Барышников, А.Ю. Пузаченко, А.В. Абрамов}

\begin{abstract}
РЕЗЮМЕ. Изучена изменчивость щечных зубов у 661 экземпляра палеарктических барсуков. Анализировались географическое распределение размерных и морфотипических признаков зубов. Подтверждено наличие двух групп барсуков (“западная” и “восточная”), рассматриваемых как аллопатрические виды Meles meles and M. anakuma. Мелкие барсуки из юго-западной Норвегии описаны как отдельный подвид M. meles milleri ssp. nov. Установлены мозаичность распределения зубных признаков и разные направления специализации щечных зубов. На основе палеонтологического материала предполагается, что оба вида произошли от позднеплиоценового барсука M. thorali, их дивергенция началась в раннем плейстоцене, а обособление на видовом уровне — в среднем плейстоцене.
\end{abstract}

КЛЮЧЕВЫЕ СЛОВА. Meles, зубы, географическая изменчивость, систематика, эволюция, Евразия.

\section{Introduction}

Taxonomy of the genus Meles Brisson, 1762 is a major issue in the study of the family Mustelidae. Eurasian badgers are usually placed in one species Meles meles (Linnaeus, 1758), which shows geographic differences in the face "mask" pattern, skull structure, and presence of the first premolars P1 and p1 (Allen, 1938; Ellerman \& Morrison-Scott, 1951; Petrov, 1953; Heptner et al., 1967; Corbet, 1978; Long \& Killingley, 1983). According to another point of view the genus Meles is heterogeneous and includes $2-3$ species. Some authors (Kastschenko, 1902; Satunin, 1914; Ognev, 1931; Neal, 1948) placed European and Asian badgers in separate species M. meles and M. leptorhynchus Milne-Edwards, 1867, the Volga River being regarded as their boundary. Later V.G. Heptner (Heptner et al., 1967; Heptner, 1968) defined three regional "groups of subspecies": "meles" (Europe eastwards up to Volga River, Caucasus, southern
Middle Asia), "arenarius-leptorhynchus" (Europe east of the Volga River, Urals, Kazakhstan and Siberia up to Transbaikalia) and "amurensis-anakuma" (Amur Region and Primorskii Territory).

Baryshnikov \& Potapova (1990) studied variation of dentition in badgers and concluded that there are two allopatric species $M$. meles and $M$. anakuma Temminck, 1844, with their boundary passing along the Volga River, Caspian Sea, Kara-Kum Desert and Fergana Valley. It was noted that both species were different also in the os malleus proportions and the baculum (os penis) structure. This point of view was accepted by some zoologists (Lüps \& Wandeler, 1993; Stubbe et al., 1998).

Data on mitochondrial DNA support the division of Eurasian badgers into European and Asian forms; specimens from Japan are more separated within the latter group (Kurose et al., 2001). Taxonomic rank of the separated groups remained undefined. 
Table 1. Material examined.

\begin{tabular}{|l|c|}
\hline Collections & Number of specimens \\
\hline Zoological Institute, Russian Academy of Sciences, St. Petersburg (ZIN) & 165 \\
\hline Zoological Museum, University of Moscow (ZMMU) & 188 \\
\hline Zoological Museum, University of Helsinki (ZMUH) & 56 \\
\hline Natural History Riksmuseum, Stockholm (NHR) & 48 \\
\hline Museum of Natural History, London (MNH) & 99 \\
\hline Museum für Naturkunde der Humboldt-Universität zu Berlin (MHUB) & 10 \\
\hline Institute of Systematics and Evolution of Animals, Krakow (ISEA) & 5 \\
\hline Muséum National d'Histoire Naturelle, Paris (MNHN) & 66 \\
\hline Museo Civico di Zoologia, Roma (MCZR) & 2 \\
\hline Smithsonian Institution (Natural History Museum), Washington DC (SI) & 17 \\
\hline Field Museum of Natural History, Chicago (FM) & 5 \\
\hline
\end{tabular}

However other authors continue regarding M. meles a single species which displays clinal variation in cranial size and shape across Eurasia (Wozencraft, 1993; Lynch, 1994; Lynch et al., 1997), or divide genus Meles into three species (M. meles, M. leucurus (Hodgson, 1847) and $M$. anakuma), proceeding from the difference in fur coloration, skull proportions and shape of baculum in animals from Japan (Abramov, 2001, 2002).

Because of the taxonomic disagreement there is a need to conduct a more detailed study of geographic variation of Eurasian badgers. We have undertaken a new analysis of dentition variation in genusMeles, since dental characters to a lesser extent than craniometrical ones depend on age and sex of the animal and allow to use paleontological material. The largest set of badger specimens, covering the entire distribution range was studied. Morphotypical and size differences between the samples were analyzed using multivariate methodology.

\section{Material and methods}

Material. 661 skulls from 11 museums of the world were examined (Tab. 1). Dental measurements were made for all specimens of which 435 had a full set of teeth. Morphotypes of teeth were defined for 534 individuals. Composition of both samples analyzed is somewhat different because morphotypes were determined for upper teeth only.

The skulls examined were placed in 25 geographic samples: 1) Norway (south-western part; $n=8) ; 2$ ) Sweden $(n=41)$; 3) Finland ( $n=56) ; 4)$ England/Ireland $(n=41) ; 5)$ France $(n=65)$; 6) Spain ( $\mathrm{n}=7)$; 7) Middle Europe (Netherlands, Germany, Switzerland, Italy, Austria, Poland, Rumania, Bulgaria; $n=20$ ); 8) Crete ( $n=3)$; 9) European Russia (as far as Volga River to east; $\mathrm{n}=93)$; 10) Ukraine $(\mathrm{n}=21)$; 11) N Caucasus (Northern Caucasus, $n=26)$; 12) Transcaucasia $(\mathrm{n}=22)$; 13) Near East (Turkey, Syria, Israel, Iraq; n=13); 14) Iran/Turkmenistan (Iran and south of Turkmenistan, $\mathrm{n}=14$ ); 15) Tajikistan (southern part of Uzbekistan and Tajikistan, n=23); 16) Zhiguli (Zhiguli Nature Reserve; $n=4)$; 17) Volga/Ural (Ural Mountains, and region between Volga River and Ural Mountains; $n=29)$; 18) Kazakhstan (Kazakhstan, northern part of Turkmenistan, northern part of Uzbekistan, western part of China; $n=62)$; 19) Kirghizia ( $\mathrm{n}=15) ; 20)$ Tibet ( $\mathrm{n}=3) ; 21$ ) Mongolia/China (Mon- golia, northern part of China; $\mathrm{n}=32)$; 22) South Siberia ( $\mathrm{n}=26)$; 23) Russian Far East ( $\mathrm{n}=16)$; 24) Korea/China (north-eastern part of China, Northern Korea; $n=3)$, 25) Japan $(n=18)$.

The study also comprised the fossil badgers: Late Pliocene M. thorali $(\mathrm{n}=6)$ from France (Saint Vallier), collection of Musée Guiment d'Histoire Naturelle, Lyon (MHNL), and Late Pleistocene M. meles ( $\mathrm{n}=7$ ) from Azerbaijan (Binagady), collection of Zoological Institute, Russian Academy of Sciences, St. Petersburg (ZIN).

Methods. For each specimen, the upper (P4 and M1) and lower $(\mathrm{p} 2, \mathrm{~m} 1, \mathrm{~m} 2)$ cheek teeth were measured, presence of the first premolars (P1 and p1) was assessed, and morphotypes of the upper cheek teeth were identified. The heavily worn teeth were not examined.

Method of measurements on the cheek teeth is shown in Fig. 1. The talonid length for $\mathrm{m} 1$ was measured on the tooth lingual side. Dimensions were taken with dial caliper with accuracy $0.1 \mathrm{~mm}$.

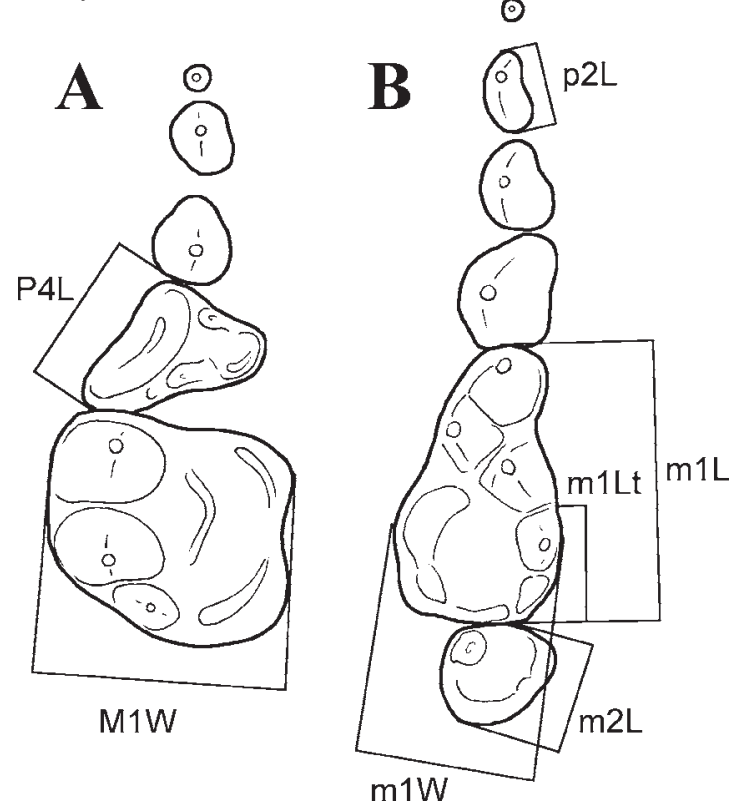

Figure 1. Tooth measurements.

A - upper teeth (P4L - length of P4; M1W - width of M1); B lower teeth ( $\mathrm{p} 2 \mathrm{~L}$ - length of $\mathrm{p} 2 ; \mathrm{m} 1 \mathrm{~L}$ - length of $\mathrm{m} 1 ; \mathrm{m} 1 \mathrm{Lt}-$ talonid length of $\mathrm{m} 1 ; \mathrm{m} 1 \mathrm{~W}$ - width of $\mathrm{m} 1 ; \mathrm{m} 2 \mathrm{~L}$ - length of $\mathrm{m} 2$ ). 

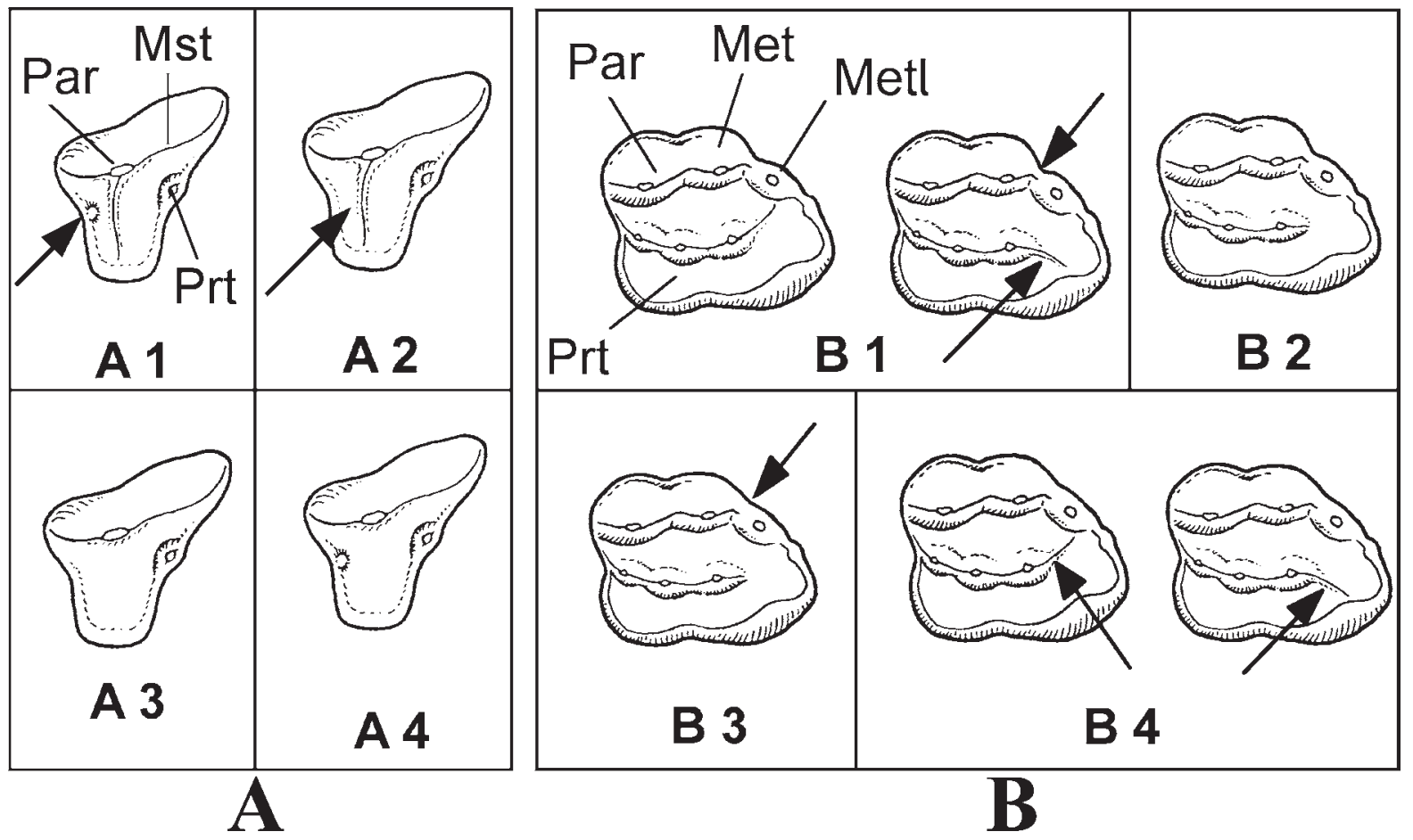

Figure 2. Tooth morphotypes.

A - morphotypes of P4; B — morphotypes of M1. Description see in text. Abbreviations: Par — paracone, Prt — protocone, Met — metacone, Metl — metaconule, Mst — metastylar blade.

The analysis revealed no sexual dimorphism in size and morphotypes of the cheek teeth that corresponds to the results of other researchers (Lüps \& Roper, 1988). Therefore males and females were examined together.

Two morphotypes were established for the first premolars P1 and p1: 1) tooth present (1), 2) tooth absent (0). The development of $\mathrm{P} 1 / \mathrm{p} 1$ was assessed by presence of the tooth alveoli at least in one tooth row.

The morphotypical variability was examined for P4 and M1. In contrast with earlier study of Baryshnikov \& Potapova (1990), lower molars $\mathrm{m} 1$ and $\mathrm{m} 2$ were not taken into consideration, since their morphotypes appeared to be rather ambiguous.

The morphotypes of $\mathrm{P} 4$ are based on the presence of a small cusp developed on the precingulum at the base of paracone's lingual anterior ridge as well as on the occurrence of the lingual ridge running from the paracone apex to the tooth inner projection in front of the protocone (Fig. 2A):

A1 - a small cusp on precingulum and lingual ridge of paracone developed; A2 - a small cusp lacking, lingual ridge expressed; A3 - both the cusp and ridge absent; A4 - a small cusp expressed, lingual ridge lacking.

The morphotypes of M1 are characterized by presence of incision on the crown labial margin, which is formed as a result of the metaconule shift in respect to metacone and by the extension of postprotocrista posterior to the level of protocone (Fig. 2B):

B1 - labial incision between the metacone and metaconule well developed, postprotocrista long and reaching metaconule or crown lingual margin; B2 - incision between metacone and metaconule well developed, postprotocrista short and not reaching metaconule or crown lingual margin; B3 - labial incision absent, postprotocrista short; B4 - outer incision absent, postprotocrista long and reaching metaconule or crown lingual margin.

\section{Methodology}

The common criteria for choice of the mathematical techniques for data analysis are both an adequacy to the initial "hypotheses" about the "nature" of data and reproducibility/ comparability of the results. It should be noted that the "nature" of the data collected is often reflected in deviation of their distribution from the model (canonical) distribution (e.g., normal, log-normal). The particular criterion of our choice is the opportunity of effective discovering and describing the general properties of the original set of data.

In this paper, we test several formal "null" hypotheses (H0) on the nature of object's variability. The main hypothesis $\mathrm{HO}$ (1): the variability among set of objects is stochastic (case of maximal diversity) versus stochastic variability is limited that is shown in some order (structure) in the data (e.g. correlation). In the context of this work, if the main null hypothesis is rejected, we have an opportunity to test hypotheses about geographical reason for limiting stochastic variability. The geographical hypothesis $\mathrm{H0}(2)$ is formulated as follows: the variability does not depend on the position of objects in the geographical space.

At the beginning of the analysis, the hypotheses of absence of correspondence between variability of objects with sex and age classes (young, adult and old) were tested. The age classes were defined on the characters of skull structure (including development of crests and degree of suture closing). Non-parametric Kruskal-Wallis ANOVA and median test were used for qualitative variables, and for quantitative 
variables parametric ANOVA was used (Sokal \& Rohlf, 1981). For all the variables and potential factors, there were no statistical reasons to reject the preliminary hypothesis.

The testing of our interval variables has shown that, as a rule, the normality of distributions was not observed, but the absolute majority among distributions was not like any canonical distribution. Therefore, we had to reject parametric multivariate "dimension-reducing" methods and use their nonparametric analogue - multidimensional scaling (MDS) for investigation of the variables interaction (Shepard, 1962; Kruskal, 1964; Davison \& Jones, 1983). We have chosen this method because MDS is much more flexible as regards the types of input data and is more correct for nonlinear case than the common linear parametric multivariate techniques (James \& McCulloch, 1990).

Similarity of the variability in the different variables reflected in the matrixes with both gamma rank correlation coefficients, $\gamma$ (Goodman \& Kruskal, 1954) (nominal variables, morphotypes) or Spearman rank correlation coefficients, $r$ (Sokal \& Rohlf, 1981) (interval variables). The matrixes were input in multidimensional scaling and the result was represented in multidimensional space. The inefficient use of any "dimensional reduce" technique was shown for interval variables, as they were practically uncorrelated. In contrast nominal variables were significantly correlated.

Because we have a large data set there was no the technical reason for use MDS directly. Using results of the previous stage of analysis (MDS configuration for morphotypic variables) we calculated continuous presentation of nominal variables according technique described in Puzachenko et al. (1996).

According to Yu.G. Puzachenko (personal com.), let: 1) the matrix with MDS configuration (coefficients) -

$$
A=\left\|a_{i j}\right\| \text {, }
$$

$i=1, \ldots, N-$ the number of variables, $j=1, \ldots, M-$ "dimensionality" of MDS' space;

2) the variables ("points") -

$$
b^{k}=\left\{b_{i}^{k}\right\} \text {, }
$$

$i=1, \ldots, N, k=1,2 \ldots$. number of specimens

Then, for $\forall k \geq 1$ and $A^{T} b^{k}$ we have the system of the linear equations

$$
\begin{aligned}
& \left(A^{T} A\right) x^{k}=A^{T} b^{k}, \\
& x^{k}=\left(A^{T} A\right)^{-1} A^{T} b^{k},
\end{aligned}
$$

and we have opportunity for calculation $M(M<<N)$ new interval variables, $x_{M}$. This method gives a better solution in the "linear" or monotonic cases of "interaction" between variables. But in any way it gives us opportunity to use "non direct" MDS in the case with large data set (more than 250 specimens).

The interval, quantitative data was standardized to exclude influence of the "scale" of the different measurements on the results while preserving properties of their distribution. Transformation was used according to the following equation:

$$
\widetilde{x}_{i}=\frac{x_{i}-x_{\min }}{x_{\max }-x_{\min }},
$$

where $\hat{x}_{i}$ - standardized measurement, $x_{i}, x_{\min }, x_{\max }$ are observed, minimal and maximal value of $i$-th variable, accordingly.
In the case of nominal qualitative data type (morphotypes), we calculated dissimilarity matrix contained the "percent disagreement" distances. This multivariate distance is computed as a particular value of the number of matches when measurements in $i$-th specimens are not equal to the corresponding measurement in $j$-th specimens and number of variables.

On the next phase of the analysis, all objects were classified into several clusters by dissimilarity matrixes: Euclidean distances (standardized interval variables and "continuous presentation" of nominal variables) or "percent disagreement" distances (real discrete nominal variables). Agglomerative hierarchical cluster algorithm, unweighted pair-group average methods (UPGMA, Sneath \& Sokal, 1973) and Euclidean metric were used.

Note that UPGMA method defines distance between groups as the average of the distances between all pairs of objects in the two groups and the more important maximum preserves the structure of the input dissimilarity matrix. The number of clusters, which were taken into account, was determined on the basis of the following assumptions (Puzachenko, 2001). If variability of specimens is close to stochastic (accordingly, Euclidean distances in the dissimilarity matrix have also stochastic variation) with normal distribution then, on each subsequent step of the UPGMA classification algorithm, the increase of distance between new groups must be approximately equal to average increase at the previous steps (linear dependence between the step of classification and the linkage distance) and distribution of linkage distances must be normal. It is easy to find on plot the close interval where the graphic of linkage distance robustly deviates from the linear model. Linkage distance corresponding to this interval (or point) is minimal, "statistically" proved formal "cluster cutoff" value. Subgroups that join at a distance below this value are put in the same cluster. Subgroups that join at a distance greater than this value are placed in different clusters, which have the statistical reasons. In the present study we use the Kolmogorov-Smirnov test (K-S $d$ ) for testing the linkage distance distribution on normality.

The canonical discriminant analysis (Jennrich, 1977) used for classifying the specimens with non complete set of measurements. Also, discriminant analysis used for testing the "quality" of the groups were created by cluster analysis.

We used crosstabulation analysis to compare results of classifications of objects by morphotypes and size of their teeth with belonging of specimens to different geographical samples. Pearson Chi-square was used in this analysis as statistical test (Sokal \& Rohlf, 1981).

The geographical samples classification was based on the means of the standardized variables or MDS axes. The procedure included hierarchical UPGMA classification. Also, the results were presented in multidimensional MDS space as described above.

\section{Results}

Character pattern. Morphotypical variation of teeth $\mathrm{P} 1, \mathrm{~m} 1$ and $\mathrm{p} 1$ in general demonstrate high concordance $(\gamma=0.62-0.84)$ (Fig. 3A, B). Variation of P4 is relatively independent of variation of M1 and P1 and has weak negative correlation with $\mathrm{p} 1(\gamma=-0.51)$. Thus, space dimension is equal to 2 , which permits reproducing morphotypical variation without essential losses of information. Shown in Fig. $3 \mathrm{~B}$ is relative position of characters in the space of two MDS axes. 
$\mathrm{D}, \%$

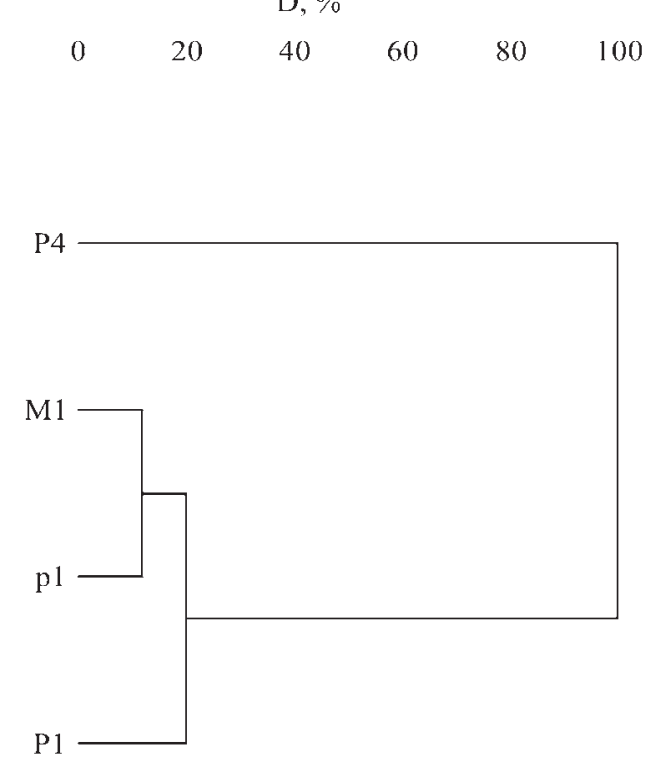

\section{A}

$\mathrm{D}, \%$
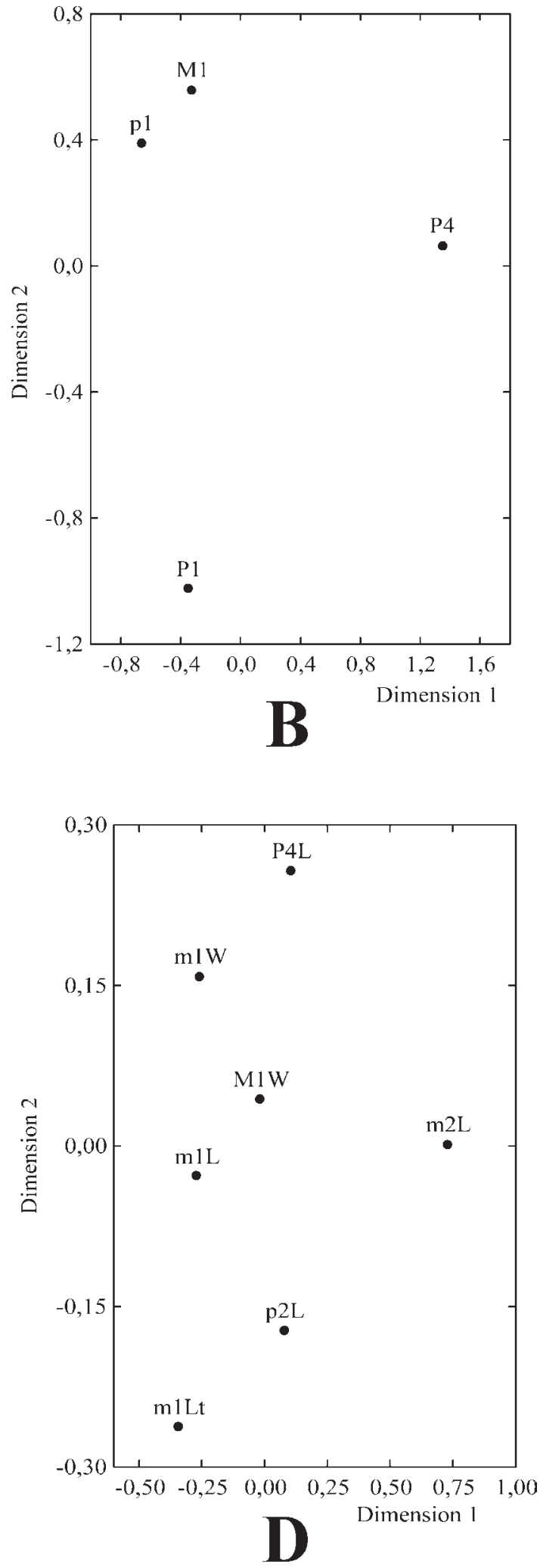

Figure 3. Clustering (UPGMA method) of the tooth characters, based on the rank correlation matrices (Kendall, $\gamma$ and $r_{s}$ ), and their places in multidimensional scaling space.

A, B - morphotypes, C, D - measurements; D, \% - relative distance, Dimension 1-2 - MDS axes. 
TABle 2. Distribution (\%) OF THE DIfFERENT MORPHOTYPES IN P4, M1, P1, AND P1 BY TWO CLUSTERS (I AND II) (MAXIMUM IN BOLD).

\begin{tabular}{|c|c|c|c|c|c|c|}
\hline \multirow{2}{*}{ Tooth } & \multirow{2}{*}{ Cluster } & \multicolumn{4}{|c|}{ Morphotype } & \multirow{2}{*}{$X^{2}, p$} \\
\hline & & $1(0)$ & 2 (1) & 3 & 4 & \\
\hline \multirow{2}{*}{ P4 } & I & 50.7 & 25.1 & 12.7 & 11.5 & \multirow{2}{*}{$\begin{array}{c}146.1 \\
<0.000001\end{array}$} \\
\hline & II & 3.9 & 61.8 & 18.5 & 15.7 & \\
\hline \multirow{2}{*}{ M1 } & 1 & 2.3 & 4.2 & 35.8 & 57.8 & \multirow{2}{*}{$\begin{array}{c}328.4 \\
<0.000001\end{array}$} \\
\hline & II & 54.5 & 26.4 & 8.9 & 10.1 & \\
\hline \multirow{2}{*}{ P1 } & I & 39.7 & 60.3 & & & \multirow{2}{*}{$\begin{array}{c}145.2 \\
<0.00001\end{array}$} \\
\hline & II & 91.1 & 8.9 & & & \\
\hline \multirow{2}{*}{ p1 } & I & 2.5 & 97.5 & & & \multirow{2}{*}{$\begin{array}{c}574.7 \\
<0.000001\end{array}$} \\
\hline & II & 98.3 & 1.7 & & & \\
\hline
\end{tabular}

Variation of the majority of the studied size characters is weakly correlated, distance is less than $40 \%$ (Fig. $3 \mathrm{C}, \mathrm{D})$. Maximum value of $r$ is $0.69(\mathrm{M} 1 \mathrm{~W}, \mathrm{~m} 1 \mathrm{~W})$. The maximum independent variation is demonstrated by $\mathrm{m} 2 \mathrm{~L}$ and m1Lt. The biological interpretation of this phenomenon is that variation of sizes of separate teeth within a dental row and even of lengths and widths of the same teeth are nearly independent of each other.

Classification of sample by morphotype. On the upper hierarchical level classification is distinctly differentiated into two groups ("cut-off" level D=75\%, Fig. 4A). In Tab. 2 distribution of teeth morphotypes by these clusters and statistical check of null hypothesis of their relationship are shown.

Tab. 3 includes data on distribution of different clusters in geographic samples. It should be noted that on the whole this distribution is non-stochastic (Chisquare $=461.7, \mathrm{df}=24, \mathrm{p}<0.00001$, which proves existence of geographic variation. It may be assumed that specimens from the "western" part of the range belong mostly to I morphotypical cluster and from "eastern" to II morphotypical cluster (Fig. 4A). Morphotypical characterization of the forms is given in Tab. 2 .

Classification of sample by tooth size. On two upper hierarchical levels of classification (Fig. 4B) three clusters were separated ("cut-off" level $\mathrm{D}=25 \%$ ). K$\mathrm{Sd}=116(\mathrm{p}<0.01)$, which indicates both statistically significant deviation of linkage distance from the normal distribution and rejects the hypothesis of stochastic variation. Tab. 4 includes mean values of teeth in these three clusters. It follows from Tab. 4 that the first cluster includes specimens with large teeth, the third cluster includes specimens with the smallest teeth, and the second cluster with teeth of intermediate size. Characters p2L (Fig. 5), M1W and $\mathrm{m} 1 \mathrm{~W}$ are of major importance for differentiation of the sample into three clusters. At the least degree the differences are manifested in $\mathrm{m} 2 \mathrm{~L}$ and $\mathrm{m} 1 \mathrm{~L}$. Nevertheless, statistically significant differences $(p<0.00001)$ have been discovered between clusters by all characters.

Results of discriminant analysis (Fig. 6A) show that the described variation of teeth is continuous, including two independent components. The first and second clusters are divided by the first discriminant axis (canonical scores correlate positively with teeth sizes). The first cluster is formed by badgers with the largest teeth including those with a maximum length of $\mathrm{p} 2$, a second cluster are badgers with relatively small teeth (Fig. 6B). The third cluster is differentiated from the first two. The second axis correlates negatively ( $\mathrm{r}=-0.74$, Fig. 6C) with $\mathrm{m} 1 \mathrm{~L}$ and to a lesser extent with $\mathrm{m} 2 \mathrm{~L}(\mathrm{r}=-0.54)$.

TABLE 3. Distribution (\%) OF the tWo MORPHOtYPiCAL ClUSters (I, II) BY THE GEOGRAPHICAL SAMPLES, $N$ - SAMPLE SIZE.

\begin{tabular}{|l|c|c|c|l|c|c|c|}
\hline \multirow{2}{*}{ Geographical sample } & \multicolumn{3}{|c|}{ Cluster } & \multirow{2}{*}{ Geographical sample } & \multicolumn{3}{|c|}{ Cluster } \\
\cline { 2 - 6 } & $\mathrm{I}$ & $\mathrm{II}$ & $n$ & & $\mathrm{I}$ & $\mathrm{II}$ & $n$ \\
\hline Norway & 100.0 & 0.0 & 8 & Iran/Turkmenistan & 81.8 & 18.2 & 11 \\
\hline Sweden & 100.0 & 0.0 & 41 & Tajikistan & 81.3 & 18.7 & 16 \\
\hline Finland & 98.0 & 2.0 & 49 & Zhiguli & 50.0 & 50.0 & 4 \\
\hline England/Ireland & 97.2 & 2.8 & 36 & Volga/Ural & 7.4 & 92.6 & 27 \\
\hline France & 92.5 & 7.5 & 53 & Kazakhstan & 12.5 & 87.5 & 48 \\
\hline Middle Europe & 100.0 & 0.0 & 15 & Kirghizia & 0.0 & 100.0 & 14 \\
\hline European Russia & 92.2 & 7.8 & 77 & Tibet & 0.0 & 100.0 & 2 \\
\hline Ukraine & 93.7 & 6.3 & 16 & Mongolia/China & 0.0 & 100.0 & 28 \\
\hline N Caucasus & 87.5 & 12.5 & 16 & South Siberia & 0.0 & 100.0 & 16 \\
\hline Spain & 100.0 & 0.0 & 7 & Russian Far East & 0.0 & 100.0 & 9 \\
\hline Crete & 0.0 & 100.0 & 1 & Korea/China & 0.0 & 100.0 & 1 \\
\hline Transcaucasia & 84.6 & 15.4 & 13 & Japan & 6.3 & 93.8 & 16 \\
\hline Near East & 80.0 & 20.0 & 10 & & & & \\
\hline
\end{tabular}



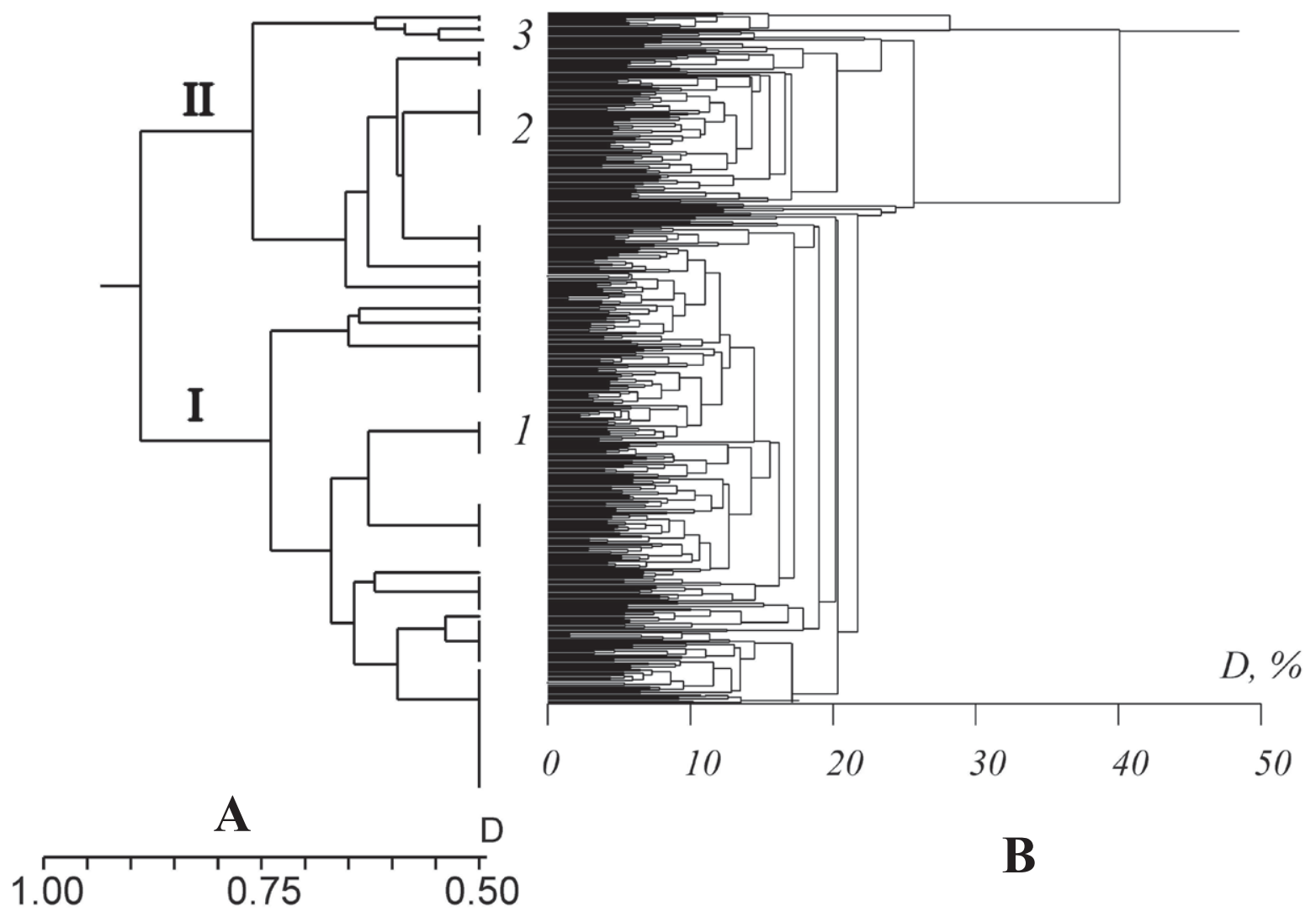

B

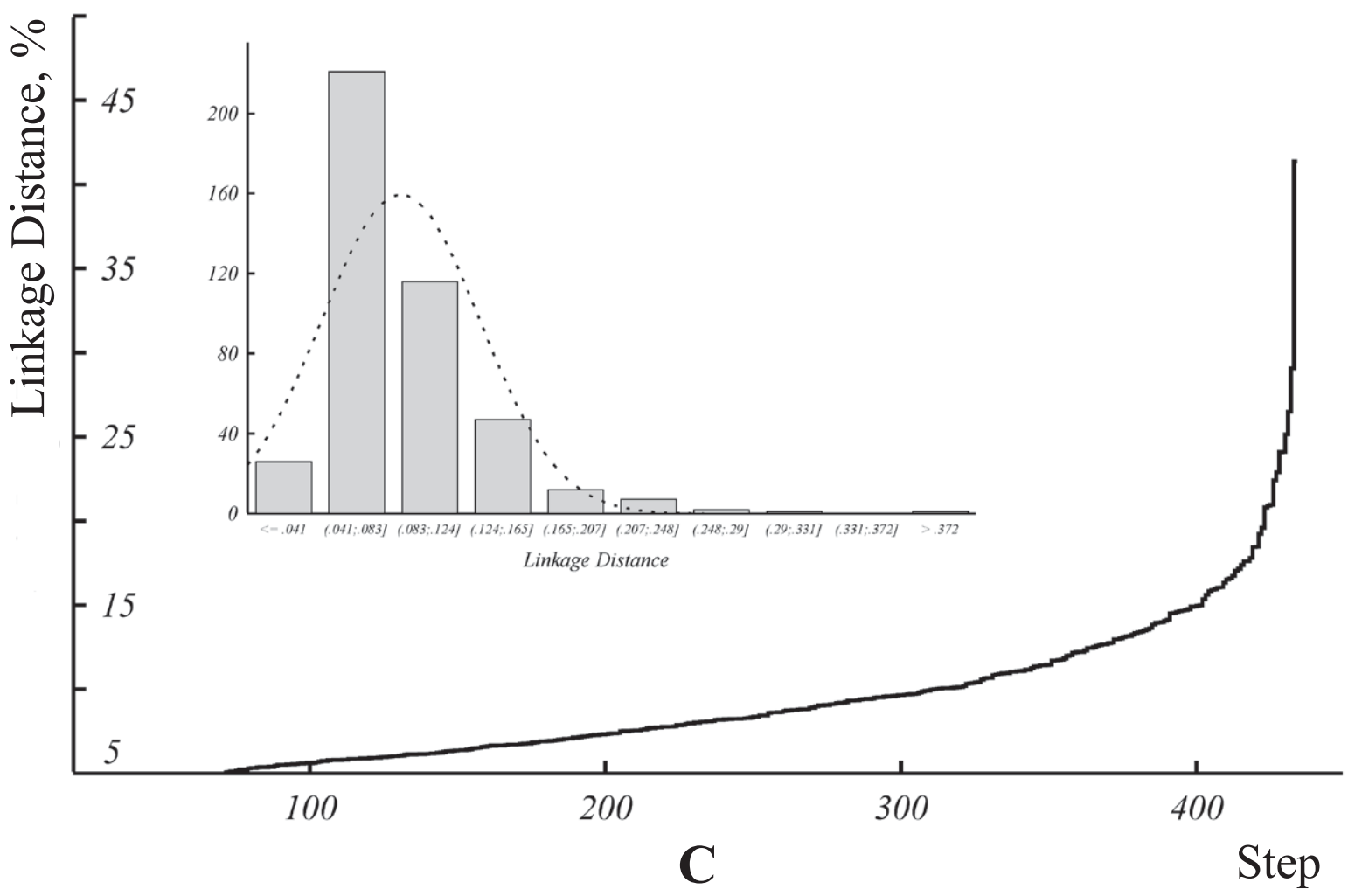

Figure 4. Clustering (UPGMA method) of the specimens based on:

A - morphotypes (clusters I, II; Cophenetic Correlation=0.89); B — tooth measurements (clusters 1, 2, 3; Cophenetic Correlation $=0.73$ ); $\mathrm{C}$ - plot of linkage distances across clustering steps (Step) and its distribution for classification which is shown on the Fig. 4B. 
Table 4. Mean Value and standard eRror of the tooth characters IN THE THREE MORPHOLOGICAL CLUSTERS (1-3), $H$ - KRUSKal-Wallis test.

\begin{tabular}{|l|c|c|c|c|c|c|c|}
\hline Cluster & $\mathrm{P} 4 \mathrm{~L}$ & $\mathrm{M} 1 \mathrm{~W}$ & $\mathrm{p} 2 \mathrm{~L}$ & $\mathrm{~m} 1 \mathrm{~L}$ & $\mathrm{~m} 1 \mathrm{~W}$ & $\mathrm{~m} 1 \mathrm{Lt}$ & $\mathrm{m} 2 \mathrm{~L}$ \\
\hline 1 & $8.57 \pm 0.025$ & $11.78 \pm 0.034$ & $4.66 \pm 0.020$ & $15.98 \pm 0.041$ & $7.51 \pm 0.022$ & $7.25 \pm 0.032$ & $5.67 \pm 0.029$ \\
\hline 2 & $8.10 \pm 0.045$ & $10.53 \pm 0.048$ & $3.32 \pm 0.036$ & $15.60 \pm 0.071$ & $6.82 \pm 0.038$ & $6.75 \pm 0.049$ & $5.41 \pm 0.046$ \\
\hline 3 & $7.20 \pm 0.176$ & $9.44 \pm 0.158$ & $2.50 \pm 0.057$ & $12.69 \pm 0.235$ & $5.66 \pm 0.105$ & $5.81 \pm 0.215$ & $4.19 \pm 0.096$ \\
\hline$H$ & 112.1 & 264.9 & 303.5 & 66.7 & 211.2 & 96.4 & 60.3 \\
\hline
\end{tabular}

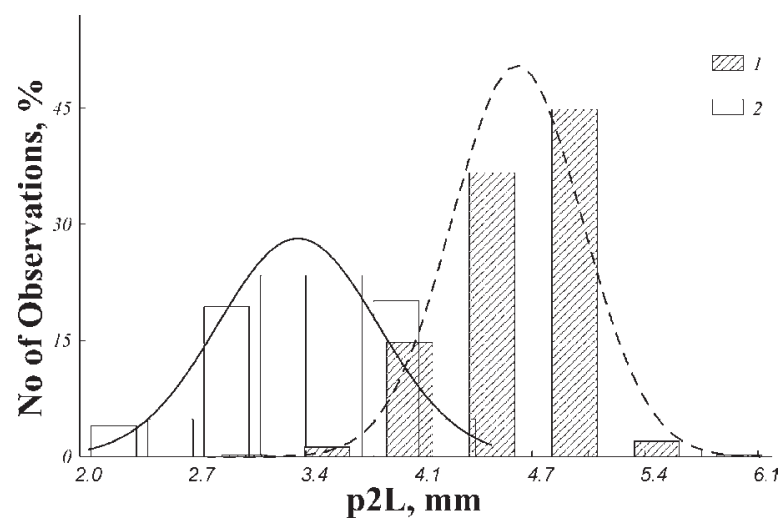

Figure 5. Distribution of p2 length in the "western" (1) and "eastern" (2) badgers.

Thus, the third cluster includes not only the specimens with the smallest teeth, but also those having a minimum length of molars $\mathrm{m} 1$ and $\mathrm{m} 2$.
In Tab. 5 distribution of these clusters by the geographic samples is shown. The first cluster fully correlates with the "western" group earlier separated by morphotypes, the second and third cluster fully correlate with the "eastern group". Representatives of the third cluster characterized by original variation are mostly localized on Japanese islands. There is a sharp boundary between "western" and "eastern" badgers. Noteworthy is the peculiar character of badgers inhabiting southwestern Norway having smaller teeth, as compared to populations from Sweden and Finland and a relatively large portion of "large-toothed" animals in the south of Siberia, in Kazakhstan and Western China.

Integrated study of geographic variation of teeth. Variables used for describing geographic variation were sample mean values of discriminant axes (size variation) and mean values of variables represented as a continuous form of morphotypical variation.

Dendrogram in Fig. 7A shows classification by two groups of variables. Fig. 7B shows position of variables in space of MDS axes. Two groups of samples compa-
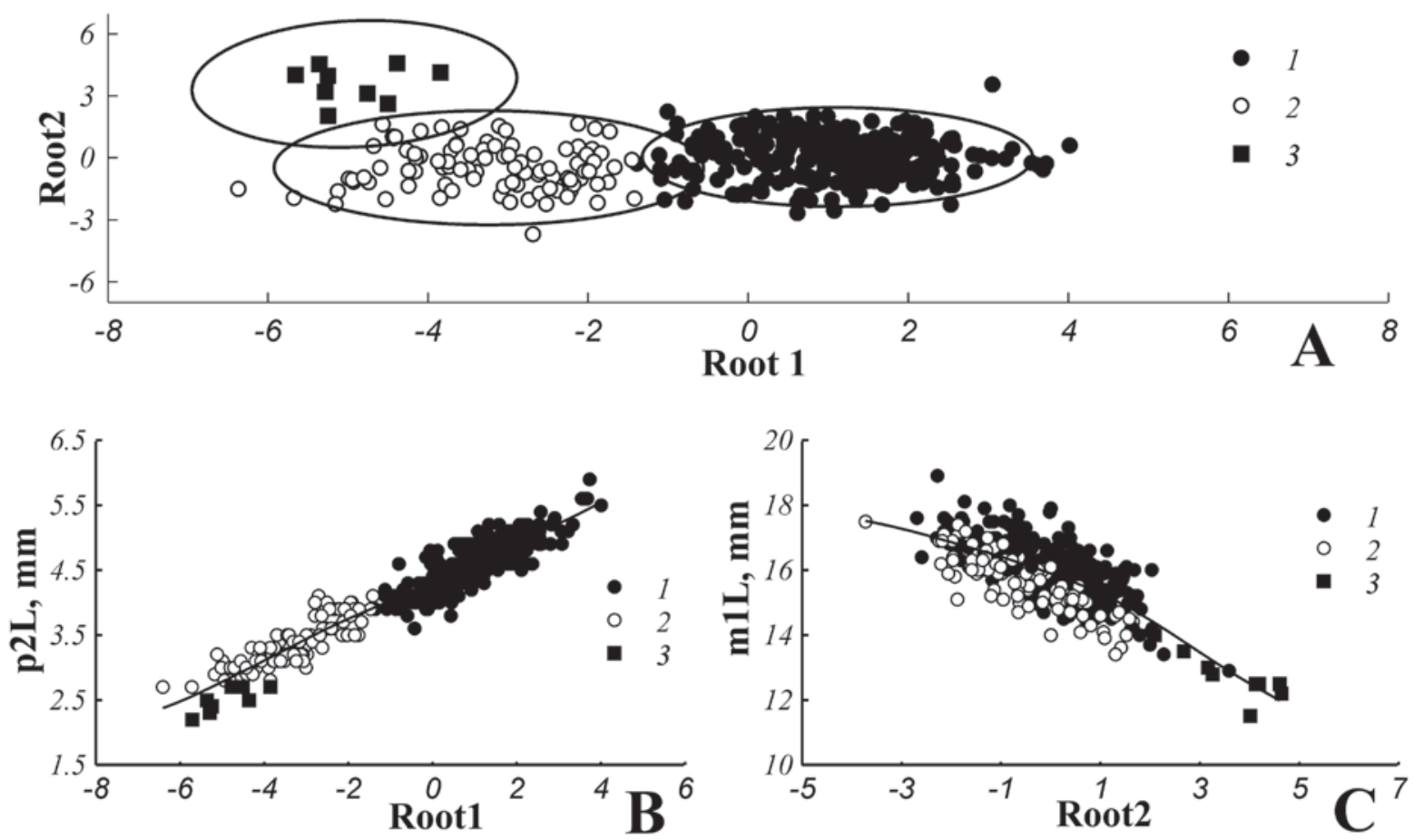

Figure 6. The results of discriminant analyses of three morphological clusters.

A - scatterplot of canonical scores for three morphological clusters $(1,2,3)$ in the space of two first canonical discriminant variables (Root 1, Root 2); ellipses - 95\% confidence bands. B, C - scatterplots of canonical variables and two dental characters $\mathrm{p} 2 \mathrm{~L}$ and $\mathrm{m} 1 \mathrm{~L}$. 
Table 5. Distribution (\%) of the three morphological Clusters (1-3) BY THE GEOGRAPHICAL SAMPLES, $N$ - SAMPLE SIZE.

\begin{tabular}{|l|c|c|c|c|l|c|c|c|c|}
\hline \multirow{2}{*}{ Geographical sample } & \multicolumn{4}{|c|}{ Cluster } & \multirow{2}{*}{ Geographical sample } & \multicolumn{4}{|c|}{ Cluster } \\
\cline { 2 - 6 } & 1 & 2 & 3 & $n$ & & 1 & 2 & 3 & $n$ \\
\hline Norway & 75.0 & 25.0 & 0.0 & 8 & Iran/Turkmenistan & 90.9 & 9.1 & 0.0 & 11 \\
\hline Sweden & 100.0 & 0.0 & 0.0 & 41 & Tajikistan & 100.0 & 0.0 & 0.0 & 22 \\
\hline Finland & 100.0 & 0.0 & 0.0 & 55 & Zhiguli & 0.0 & 100.0 & 0.0 & 4 \\
\hline England/Ireland & 100.0 & 0.0 & 0.0 & 41 & Volga/Ural & 3.4 & 93.1 & 3.5 & 29 \\
\hline France & 100.0 & 0.0 & 0.0 & 62 & Kazakhstan & 19.2 & 80.8 & 0.0 & 52 \\
\hline Middle Europe & 100.0 & 0.0 & 0.0 & 19 & Kirghizia & 14.3 & 85.7 & 0.0 & 14 \\
\hline European Russia & 100.0 & 0.0 & 0.0 & 87 & Tibet & 33.3 & 66.7 & 0.0 & 3 \\
\hline Ukraine & 95.0 & 5.0 & 0.0 & 20 & Mongolia/China & 15.6 & 84.4 & 0.0 & 32 \\
\hline N Caucasus & 100.0 & 0.0 & 0.0 & 19 & South Siberia & 22.7 & 77.3 & 0.0 & 22 \\
\hline Spain & 100.0 & 0.0 & 0.0 & 7 & Russian Far East & 13.3 & 86.7 & 0.0 & 15 \\
\hline Crete & 100.0 & 0.0 & 0.0 & 2 & Korea/China & 0.0 & 100.0 & 0.0 & 2 \\
\hline Transcaucasia & 93.8 & 6.3 & 0.0 & 16 & Japan & 0.0 & 11.1 & 88.9 & 18 \\
\hline Near East & 91.7 & 8.3 & 0.0 & 12 & & & & \\
\hline
\end{tabular}

TABle 6. Distribution (\%) OF the difFERENT MORPHOTYPES IN P4, M1, P1, P1 BY THE "WESTERN" (I) AND "EASTERN" (II) POPULATIONS OF BADGERS (MAXIMUM IN

BOLD).

\begin{tabular}{|c|c|c|c|c|c|c|}
\hline \multirow{2}{*}{ Tooth } & \multirow{2}{*}{ Populations } & \multicolumn{4}{|c|}{ Morphotype } & \multirow{2}{*}{$\begin{array}{c}\mathrm{M}-\mathrm{L} \chi^{2} \\
\mathrm{p}\end{array}$} \\
\hline & & $1(0)$ & $2(1)$ & 3 & 4 & \\
\hline \multirow{2}{*}{ P4 } & 1 & 50.1 & 24.9 & 13.0 & 11.9 & \multirow{2}{*}{$\begin{array}{c}166.8 \\
<0.00001\end{array}$} \\
\hline & II & 1.2 & 65.2 & 18.3 & 15.2 & \\
\hline \multirow{2}{*}{ M1 } & I & 1.4 & 2.7 & 37.1 & 58.8 & \multirow{2}{*}{$\begin{array}{c}457.9 \\
<0.00001\end{array}$} \\
\hline & II & 60.9 & 31.7 & 3.7 & 3.7 & \\
\hline \multirow{2}{*}{ P1 } & I & 41.5 & 58.5 & & & \multirow{2}{*}{$\begin{array}{c}133.4 \\
<0.00001\end{array}$} \\
\hline & II & 91.5 & 8.5 & & & \\
\hline \multirow{2}{*}{ p1 } & 1 & 8.7 & 91.3 & & & \multirow{2}{*}{$\begin{array}{c}355.5 \\
<0.00001\end{array}$} \\
\hline & II & 92.7 & 7.3 & & & \\
\hline
\end{tabular}

rable with division of badgers into "western" and "eastern" (Tab. 6, 7) are distinguished. Within the "western" badgers the sample from Norway is separated and within the "eastern" badgers the sample from Japan is separated.

Thus, both independent classifications based upon analysis of morphotypical and size variation suggest separation of the two groups of badgers. At the same time these classifications have a number of characteristic features and complement each other. In both cases the geographic boundary between the groups is determined unequivocally. Thus, Eurasian badgers may be divided into two geographic groups, corresponding to those denoted earlier by Baryshnikov \& Potapova (1990) as M. meles ("western" group) and M. anakuma ("eastern" group).

\section{Discussion}

Tooth size. Analysis of size characters of cheek teeth showed a relatively independent variation of each tooth. This probably permits the dental row a rapid transformation, e.g. with the change of diet. It may be assumed that evolutionarily size characters in badges have adaptive nature. Therefore regional populations, even those that have recently separated from the neighboring populations may display distinct differences in dental metric parameters.

Among M. meles larger teeth were found in England/ Ireland and Spain samples. In the eastern part of the distribution range the portion of badgers with small teeth somewhat increases, particularly in Near East and Iran/ Turkmen samples. The smallest teeth were found in animals from the south-west of Norway, which are

Table 7. Mean and standard error of the tooth characters in the "Western" (I) and “EAstern" (II) populations of badgers, $H$ - Kruskal-Wallis test.

\begin{tabular}{|l|c|c|c|c|c|c|c|}
\hline Populations & P4L & $\mathrm{M} 1 \mathrm{~W}$ & $\mathrm{p} 2 \mathrm{~L}$ & $\mathrm{~m} 1 \mathrm{~L}$ & $\mathrm{~m} 1 \mathrm{~W}$ & $\mathrm{~m} 1 \mathrm{Lt}$ & $\mathrm{m} 2 \mathrm{~L}$ \\
\hline $\mathrm{I}$ & $8.6 \pm 0.025$ & $11.8 \pm 0.035$ & $4.7 \pm 0.020$ & $16.0 \pm 0.042$ & $7.5 \pm 0.023$ & $7.3 \pm 0.033$ & $5.7 \pm 0.029$ \\
\hline $\mathrm{II}$ & $8.1 \pm 0.047$ & $10.5 \pm 0.054$ & $3.3 \pm 0.038$ & $15.3 \pm 0.112$ & $6.8 \pm 0.043$ & $6.7 \pm 0.049$ & $5.3 \pm 0.050$ \\
\hline$H$ & 84.9 & 236.8 & 326.9 & 26.7 & 180.7 & 78.0 & 34.9 \\
\hline
\end{tabular}




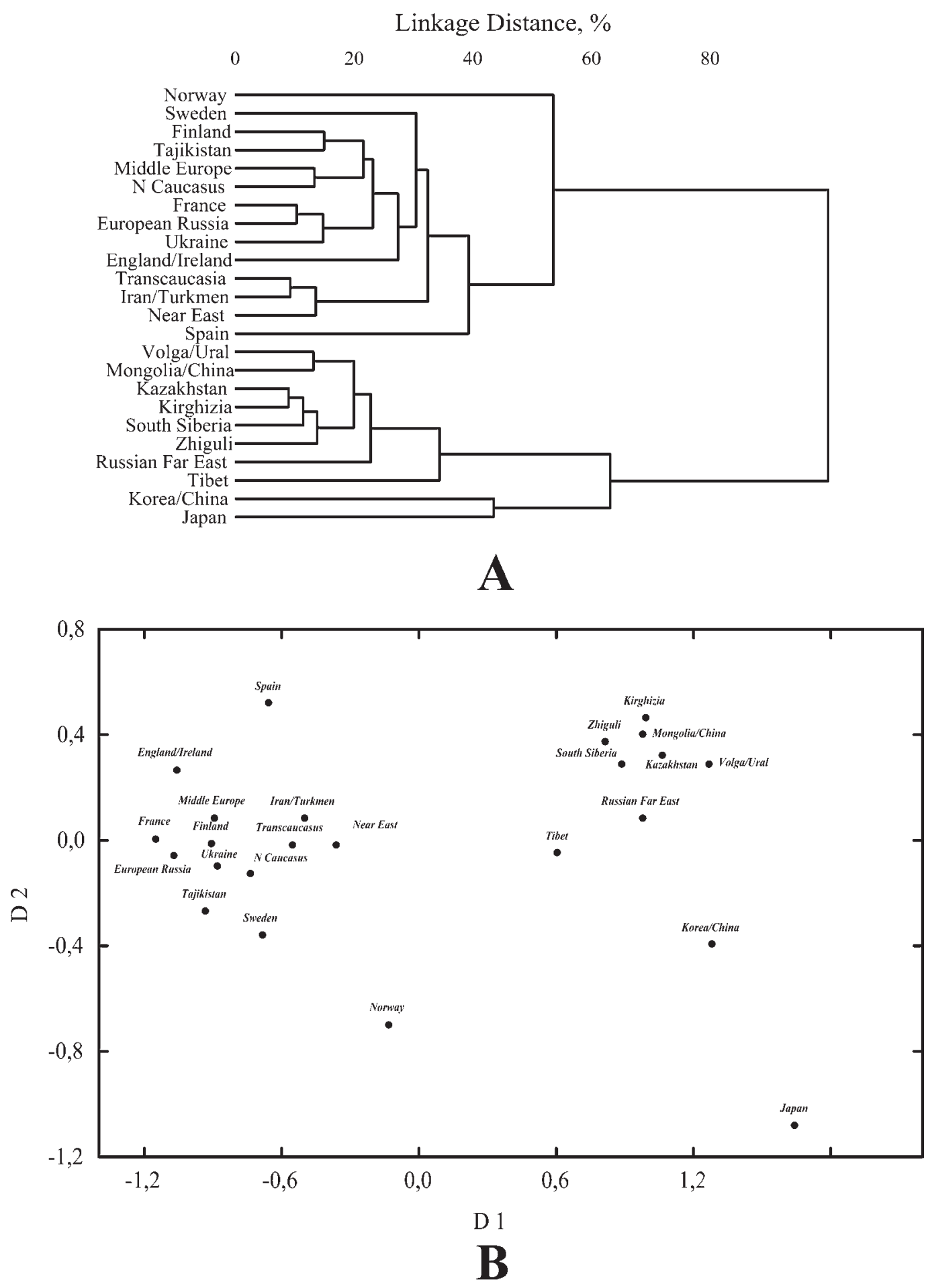

Figure 7. Classification of the geographical samples and their position in the multidimensional space.

A - UPGMA dendrogram of the geographical samples, B - position of the geographical samples in the space of two first multidimensional axes (D1, D2)

sharply different from badgers of other European samples.

In $M$. anakuma cheek teeth are smaller than in $M$. meles. Their sizes decline from Kazakhstan, South Sibe- ria and Tibet to the Russian Far East and North Korea. Japanese badgers have the smallest teeth.

Tooth morphotypes. Morphotypes of cheek teeth show a certain correlation with each other although inP4 
they change independently of morphotypes M1. Adaptive character of morphotypical variation of the studied samples is unclear. Possibly it is more "conservative" than size variation and longer period is needed for separation of badgers' populations by tooth morphotype.

Morphotypical differences between teeth of $M$. meles and M. anakuma are more pronounced than size ones. Western populations of M. meles including the Norwegian one are very similar, however in the southeast of its distribution range the portion of morphotypes characteristic also of $M$. anakuma increases.

$M$. anakuma demonstrated the least morphotypical diversity of cheek teeth throughout the entire distribution range, including Japan where badgers are weakly different from animals from continental regions of Asia.

Norway badgers. The studied sample from southwestern Norway differs notably from all European populations including Scandinavian ones with small teeth.

Earlier Hysing-Dahl (1954) conducted morphometric analysis of skulls and teeth of badgers from Norway and arrived at the conclusion that they were similar to badgers from Sweden. However that author used in his research a sample comprised mostly by specimens from eastern Norway. Having analyzed measurements of specimens from south-west of Norway given by Hysing-Dahl (1954) we discovered that they matched our results. That part of Norway (west of Telemark) is inhabited by smaller badgers than the eastern part of the country (the mean of condylobasal length of skull in males 117.84 $\mathrm{mm}, \mathrm{n}=8$ and $125.56 \mathrm{~mm}, \mathrm{n}=14$ respectively). Animals from the east of Norway are similar in sizes to badgers from Sweden and Finland.

The established phenomenon of small sizes may be accounted for by the fact that extreme south-west of Norway is a refugium, where badgers whose ancestors were first to penetrate the southern Scandinavian Peninsula survived. A possible route of their dispersal passed through Denmark where subfossil teeth have on the average smaller length of $\mathrm{m} 1(16.0 \mathrm{~mm}, \mathrm{n}=38)$, than recent ones (Degerbøl, 1933). Length of $\mathrm{m} 1$ in animals from south-western Norway is even less $(14.21 \mathrm{~mm}$, $\mathrm{n}=8$ ). They could have grown smaller under the conditions of isolation, which happened to badgers in Japan. We describe badgers from south-western Norway as a new subspecies.

Meles meles milleri Baryshnikov, Puzachenko et Abramov ssp.nov.

Holotype. Skull MNH 8.8.9.10 O', Holme, Mandal, southwestern Norway.

Paratypes. Seven skulls from Holme (N. Mandal) in MNH 8.8.9.9 $\sigma^{7}$, 8.8.9.11 9 sen., 8.8.9.12 9 , 11.6.3.13 $9,11.10 .23 .2$; and in SI: 152622 O $^{7}, 152623$ O $^{7}$.

Diagnosis. The smallest European subspecies; condylobasal length of skull in males $110.7-122.0 \mathrm{~mm}$ (on the average $117.84 \mathrm{~mm}, \mathrm{n}=8$ ), in females $113.5-120.2 \mathrm{~mm}$ (on the average $117.30 \mathrm{~mm}, \mathrm{n}=8$ ) (Hysing-Dahl, 1954), length P4 6.7-8.5 $\mathrm{mm}$ (on the average $7.91 \mathrm{~mm}, \mathrm{n}=8$ ), length $\mathrm{m} 113.4-14.8 \mathrm{~mm}$ (on the average $14.21 \mathrm{~mm}, \mathrm{n}=8$ ) (original data).
Distribution. Far south-west of Norway (Rogaland, VestAgder and Aust-Agder counties).

Etymology. The new subspecies is named after famous mammalogist Dr. Gerrit Smith Miller (1872-1956) who has noted for the first time the peculiarity of the badger from the southern Norway. He gave a subspecies name, M. meles pumilus, on the label for MNH 8.8.9.10, but did not publish it. We take this specimen as a holotype of the new subspecies.

Crete and Rhodes badgers. From large islands of the Mediterranean Sea badgers occur only in Crete and Rhodes where they were described as separate subspecies M. meles arcalus Miller, 1907 and M. m. rhodius Festa, 1914.

We did not have an opportunity to study specimens from Rhodes. However we had at our disposal a photograph of skull (SI 197980) from type locality (Koskino). First premolars P1/p1 absent. Upper cheek teeth P4 and M1 show a combination of morphotypes A2/B3, characteristic of $M$. meles. To judge by length $\mathrm{m} 1$ (14 and 15 $\mathrm{mm}$; see Festa, 1914: 7), M. m. rhodius is smaller than European continental subspecies M. meles.

Material examined from Crete included skin and skull of the type specimen of $M$. m. arcalus (MNH 5.12.2.17 $\circ$, juv.), skull of the lower jaw without mandible (MNH 5.12.2.38) and isolated mandible $(\mathrm{MNH}$ 1992.462).

The head stripe pattern in the type specimen is typical of $M$. meles (light field between ears, stretches far backwards; see Baryshnikov, 2001). M. m. arcalus has small sizes (mean value of length $\mathrm{m} 1$ is $15.25 \mathrm{~mm}$, $n=2$ ), but does not differ essentially in size from other badgers from Europe.

The two skulls examined have the following morphotypes of the upper cheek teeth: P4 (A2, A4), M1 (B1, $\mathrm{B} 1)$. Combination $\mathrm{A} 2 / \mathrm{B} 1$, found in holotype is more characteristic of $M$. anakuma; a more rare combination A4/B1 occurs with approximately equal frequency in both $M$. meles and $M$. anakuma. Upper premolars $\mathrm{P} 1$ are absent in both cases. Lower premolar p2 of type specimen is small (length $3.9 \mathrm{~mm}$ ).

Thus the badger from Rhodes and Crete may be identified as a small $M$. meles, demonstrating some teeth characters occurring in $M$. anakuma. The same characteristic is observed in neighboring populations from the continental part of Asia (Fig. 8).

Zimmermann (1953) noted that animals from both islands of the Aegean Sea were similar in size and placed them in one subspecies M. meles arcalus Miller, 1907. He believed that they were close to small badgers from Asia Minor and Transcaucasia, which is confirmed by our data.

The Holocene badger from Crete in size of skull and one mandible occupies an intermediate position between recent badgers from Crete and Near East, although its another known mandible is larger (Steensma \& Reese, 1996). Probably the badger spread in the islands from the east (from Asia Minor). It could have penetrated Rhodes, and then through a chain of islands 

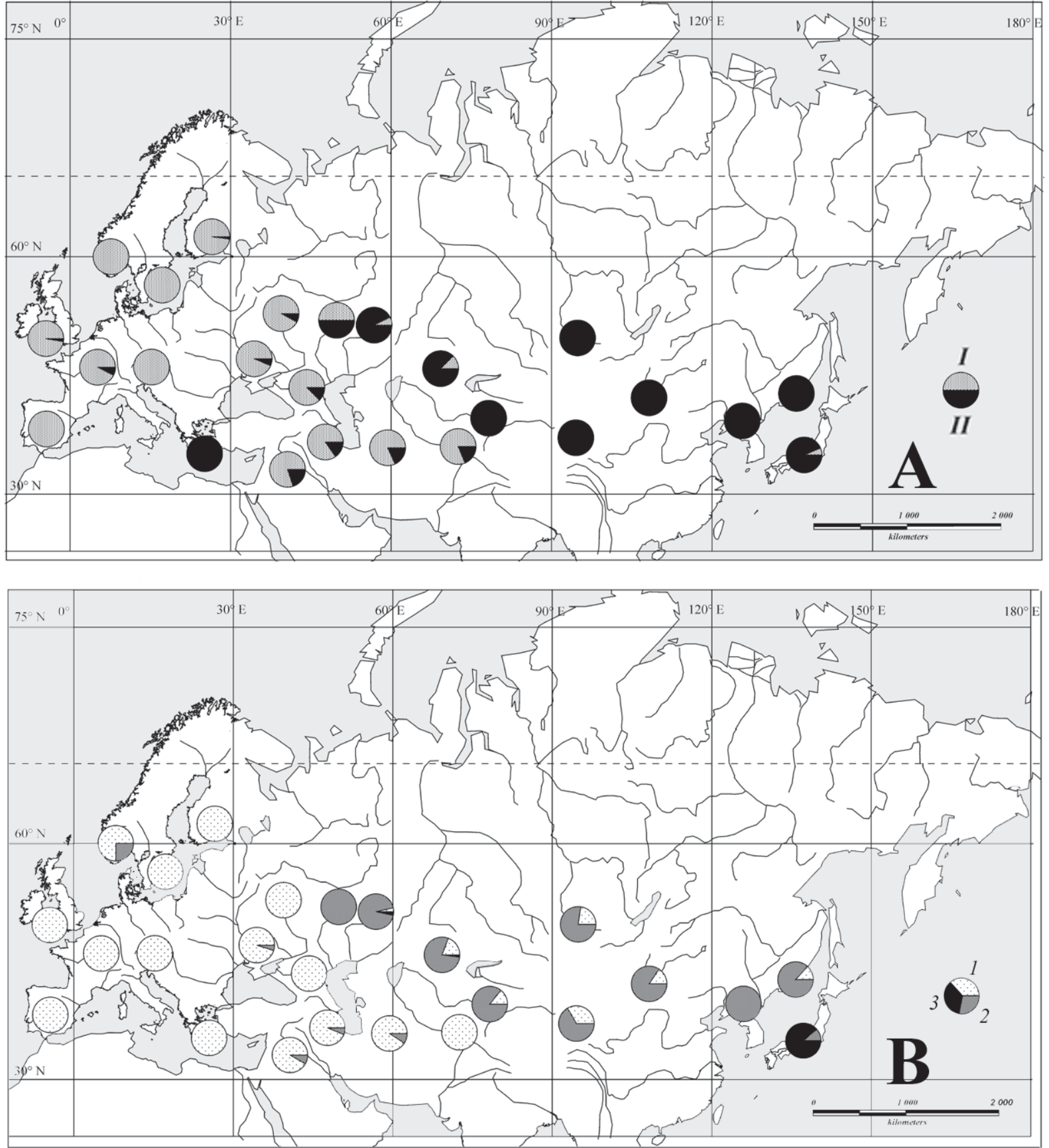

Figure 8. The ratio of different morphotypical clusters (A; I, II) and size clusters (B; 1-3) in the geographical samples.

(Karpathos, Kasos) reached Crete. The possibility of introduction by man also must not be ruled out (Evans, 1968; Steensma \& Reese, 1996).

Zhiguli badgers. It has been noted that in Zhiguli (Zhiguli Nature Reserve) situated on the right bank of the Volga River the Asian badger occurs, although its distribution range is situated on the left bank of the Volga River (data of Dr. E.M. Snegirevskaya, cited from Belyanin, 1981).

The sample examined by us includes four skulls of which two belong to M. anakuma, one to M. meles and one specimen has a mixed set of morphotypes. Possibly the last specimen (ZIN O.34606) is a hybrid. Thus in Zhiguli both species of badgers occur everywhere forming hybridization zone.

The other possible sympatric zone is situated in the west of Tien Shan, through its offshoots M. meles penetrates far north in the zone of $M$. anakuma distribution. For example, one skull (ZMMU S-2014, + sad.), whose dental characters conform to $M$. meles, is known from the vicinity of Alma-Ata in Kazakhstan (Baryshnikov \& Potapova, 1990). 
Japanese badgers. Japanese badgers form the third dimensional cluster morphometrically different from other samples of $M$. anakuma. Peculiarity of Japan badgers is determined by small sizes of their cheek teeth. That cluster includes also a small specimen (ZIN O.23858) from the Perm Region in Russia.

Under conditions of island isolation Japanese badgers could have become smaller because of restricted territory. A similar decline in sizes is displayed by some other widely distributed species of Carnivora, e.g.Cuon alpinus, Ursus thibetanus, Panthera tigris.

In size and morphotypic characters the badgers from north-eastern China and Northern Korea occupy an intermediate position between other continental populations and the Japanese population (Fig. 7B). In our opinion this points to a probable spreading badgers to the Japanese islands. Badgers could have penetrated through Korean Peninsula and Tsushima Island. Other mammal species spread in the Late Pleistocene in Honshu, Shikoku, Kyushuand northern part of Ryukyu could have reached Japan in the same way (Kamei, 1981).

Fossil remains of badgers are known in Honshu since the first half of the Late Pleistocene (Upper Kuzuü fauna). Shikama (1949) placed them in three species: $M$. leucurus kuzuuensis, M. anakuma and M. mukasianaku$m a$. To judge by the figure (Shikama, 1949: fig. 63), structure of M1 in M. mukasianakuma Shikama is peculiar: it is wider than long, lingual edge of the crown is semicircular. It is different from teeth of modern $M$. anakuma and $M$. meles.

TABle 8. Distribution (\%) OF THE DIFFERENT MORPHOTYPES IN P4, M1, P1, P1 BY THE "WESTERN" (I) AND "EASTERN" (II) POPULATIONS OF RECENT BADGERS, AND FOSSIL BADGERS FROM FRANCE (SAINT VALLIER) AND TRANSCAUCASIA (BINAGADY) (MAXIMUM IN BOLD).

\begin{tabular}{|l|l|c|c|c|c|}
\hline \multirow{3}{*}{ Tooth } & \multirow{2}{*}{ Populations } & \multicolumn{4}{|c|}{ Morphotype } \\
\cline { 2 - 6 } & & $1(0)$ & $2(1)$ & 3 & 4 \\
\hline \multirow{4}{*}{ P4 } & I & $\mathbf{5 0 . 1}$ & 24.9 & 13.0 & 11.9 \\
\cline { 2 - 6 } & II & 1.2 & $\mathbf{6 5 . 2}$ & 18.3 & 15.2 \\
\cline { 2 - 6 } & Saint Vallier & 0 & $\mathbf{8 5 . 7}$ & 14.3 & 0 \\
\cline { 2 - 5 } & Binagady & 0 & 16.7 & $\mathbf{8 3 . 3}$ & 0 \\
\hline \multirow{4}{*}{ M1 } & I & 1.4 & 2.7 & 37.1 & $\mathbf{5 8 . 8}$ \\
\cline { 2 - 5 } & II & $\mathbf{6 0 . 9}$ & 31.7 & 3.7 & 3.7 \\
\cline { 2 - 4 } & Saint Vallier & 0 & $\mathbf{1 0 0}$ & 0 & 0 \\
\cline { 2 - 4 } & Binagady & 0 & 0 & $\mathbf{7 1 . 4}$ & 28.6 \\
\hline \multirow{4}{*}{ P1 } & I & 41.5 & $\mathbf{5 8 . 5}$ & & \\
\cline { 2 - 4 } & II & $\mathbf{9 1 . 5}$ & 8.5 & & \\
\cline { 2 - 4 } & Saint Vallier & 28.6 & $\mathbf{7 1 . 4}$ & & \\
\cline { 2 - 4 } & Binagady & $\mathbf{8 5 . 7}$ & 14.3 & & \\
\hline \multirow{5}{*}{ p1 } & I & 8.7 & $\mathbf{9 1 . 3}$ & & \\
\cline { 2 - 4 } & II & $\mathbf{9 2 . 7}$ & 7.3 & \multicolumn{1}{|}{} \\
\cline { 2 - 4 } & Saint Vallier & 0 & $\mathbf{1 0 0}$ & & \\
\cline { 2 - 4 } & Binagady & 28.6 & $\mathbf{7 1 . 4}$ & & \\
\hline
\end{tabular}

In the Late Pleistocene M. leucurus kuzuuensis and M. anakuma first premolars $\mathrm{P} 1 / \mathrm{p} 1$ are absent. In M1 external notch is well developed as in recent badgers from Japan and both taxa are only different in tooth size.

Mean value of $\mathrm{m} 1$ length in the Late Pleistocene $M$. anakuma $(13.17 \mathrm{~mm}, \mathrm{n}=6)$ is the same as in recent badger from Japan (12.72 mm, $\mathrm{n}=16)$. In M. leucurus kuzuuensis the tooth is longer $(15.22 \mathrm{~mm}, \mathrm{n}=26)$, and in this index it is close to recent animals from Russian Far East $(15.03 \mathrm{~mm}, \mathrm{n}=13)$.

The range of size variation in the Late Pleistocene badgers from Honshu is only slightly higher than that in recent samples from Asian continent. Thus length of $\mathrm{m} 1$ varies from $12.6 \mathrm{~mm}$ to $17.0 \mathrm{~mm}(\mathrm{n}=32)$ in fossil Japanese specimens and from $13.2 \mathrm{~mm}$ to $16.3 \mathrm{~mm}$ $(n=15)$ in recent specimens from Russian Far East and Korea/China samples.

Thus badgers M. leucurus kuzuuensis and M. anaku$m a$ from Upper Kuzuü fauna belong to one species $M$. anakuma. Even though sizes of their teeth vary, size characters, as was mentioned above, change rapidly in the evolution of badgers.

Analysis of morphotypical variation of cheek teeth revealed no differences between recent badgers of Japan and continental Asia (combinations A3/B1, A2/B1 and A2/B2 are represented in approximately equal proportion). Tooth characters therefore give no reason to regard them as separate species.

Fossil badgers. Tooth characters of fossil badgers from two localities Saint Vallier in southeastern France and Binagady in Azerbaijan were studied.

Fossil badger from Saint Vallier was described as $M$. thorali (Viret, 1950). The faunal assemblage of Saint Vallier permits dating the locality to the Late Pliocene (MN 17) (Mein, 1990). Using recent badgers of the "western" and "eastern" groups as a "testing sample" in the procedure of discriminant analysis we classified six fossil skulls from Saint Vallier. As a result five specimens with probability of more than $90 \%$ were placed in the "western" group (Tab. 8). These specimens were characterized by large teeth sizes (mean of $\mathrm{m} 1$ length $16.25 \mathrm{~mm}, \mathrm{n}=4)$.

Five specimens have morphotypes A2/B1, one specimen - A3/B1. Both combinations are usual for $M$. anakuma and are very rare in M. meles. However the lower premolar p2 is large (mean of length is $4.83 \mathrm{~mm}$, $\mathrm{n}=6$ ), with two roots, which is typical of $M$. meles (Baryshnikov \& Potapova, 1990).

Thus, the Late Pliocene $M$. thorali demonstrated mosaicity of characters occurring in both $M$. meles (presence of first premolars P1/p1, large p2 with two roots), and in $M$. anakuma (morphotypes P4 and M1). Such mosaic pattern permits regarding $M$. thorali as a probable ancestor from which both $M$. meles and $M$. anakuma diverged.

Locality of Binagady is in the Transcaucasia near Baku. It is dated to the early Late Pleistocene (Eem, MN 25) (Baryshnikov, 2002). Seven skulls and seven mandibles were studied. On one skull P4 and M1 are absent, on some others they are strongly worn. 

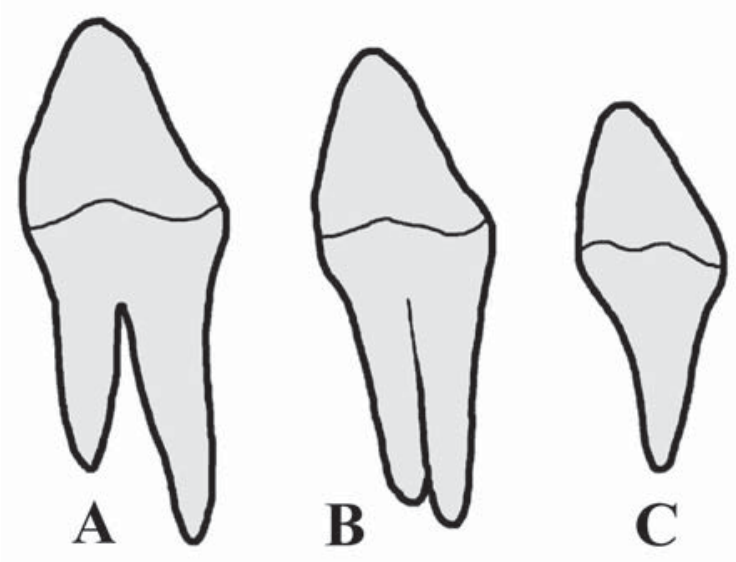

Figure 9. Transformation of roots in lower premolar $\mathrm{p} 2$. A - tooth with two roots, B - tooth with fused roots, $\mathrm{C}$ - tooth with single root.

Teeth large, length of $\mathrm{p} 2$ exceeds $4.0 \mathrm{~mm}$. Mean of $\mathrm{m} 1$ length $(15.9 \mathrm{~mm}, \mathrm{n}=6)$ is not different from the same character in the sample of recent badgers from the Transcaucasia (15.63 mm, $\mathrm{n}=14$ ).

Five specimens have morphotypes A3/B3, one specimen - A2/B3. Such combinations seldom occur in $M$. meles and are an exception in M. anakuma. The upper premolar P1 is found in one specimen only, the lower premolar $\mathrm{p} 1$ was found in five mandibles. Number of roots in premolar $\mathrm{p} 2$ varies: three specimens have one root, two specimens appeared to have fused roots, and two specimens have two separate roots.

Our study indicates that the badger from Binagady has mosaicity of morphotypical characters, but it is different than in $M$. thorali. Upper molars of Binagady badger have meles-morphotypes, other characters (reduction of premolars $\mathrm{P} 1 / \mathrm{p} 1$, number of roots inp2) vary. Similar dental mosaicity is observed in recent badgers of the Transcaucasia, but $M$. meles characters are more pronounced in them (e.g. among 21 examined specimens three specimens had p2 with one root, five specimens with two fused roots, 13 specimens with two separate roots).

Thus, in the evolution of badgers of the Transcaucasia from the beginning of the Late Pleistocene up to the recent time tendency of increasing dental characters of M. meles is observed.

Partition of $M$. meles and M. anakuma. The analysis of cheek teeth of Eurasian badgers confirmed differences in dental characters between $M$. meles and $M$. anakuma, established earlier (Baryshnikov \& Potapova, 1990; Baryshnikov, 2001).

M. meles is characterized by two-rooted p2 (specimens with two fused roots or with one root occur rarely, mostly in the Transcaucasia and Middle Asia), length of $\mathrm{p} 2$ as a rule exceeds $4.0 \mathrm{~mm}$ and external notch on M1 is absent (morphotypes B3/B4, 93.5\% of the entire sample). Predominant in 392 examined skulls are morphotypical combinations A1/B4 ( $=117)$ and A1/B3 ( $=74)$, which together comprise nearly one half $(49 \%)$ of the entire sample. Among badgers of the Transcaucasia, Near East and Tajikistan they are rare and there morphotypes A2/ $\mathrm{B} 3$ and $\mathrm{A} 2 / \mathrm{B} 4$ are most common. Combinations A2/B1 and A2/B2 were not observed in M. meles.

M. anakuma is characterized by one rooted p2 (Fig. 9), two roots have not been discovered on this tooth, which as a rule is less than $4.0 \mathrm{~mm}$ width, and by external notch on M1 (morphotypes B1/B2, 81\% of the sample). Of 170 specimens examined more than half $(58 \%)$ have morphotypical combinations A2/B1 $(\mathrm{n}=60)$ and A2/B2 $(\mathrm{n}=38)$. Morphotypes A1/B4 and A1/B3 in M. anakuma are absent.

Morphotypical differences of the two species may be used in analysis of paleontological material for establishing origin of M. meles and M. anakuma and time of their divergence.

Origin of species.As has been noted, in $M$. thorali from the Late Pliocene of France (MN 17) anterior premolars are not reduced, p2 long, two-rooted, $\mathrm{P} 4$ and $\mathrm{M} 1$ are characterized by morphotypical combination A2/B1.

Similarity with $M$. thorali is retained in the early Early Pleistocene $M$. dimitrius established for locality Gerakarou 1 in northern Greece (MN 18). It had p1, large p2 and morphotype B1 (Koufos, 1992: pl. 4, figs. 3-5, pl. 5, fig. 1).

A later species in Europe is $M$. hollitzeri from late Early Pleistocene. It was described from locality Deutsch-Altenburg 2C in northeastern Austria (Rabeder, 1976: Abb. 15-17) and then found in Untermassfeld in southeastern Germany (Wolsan, 2001: fig. 4). It was revealed that $M$. hollitzeri had $\mathrm{p} 1$ and large $\mathrm{p} 2$ with two roots. Upper cheek teeth demonstrate morphotypical combination A2/B4 for Deutsch-Altenburg 2C specimen and A4/B3 for Untermassfeld specimen. Therefore $M$. hollitzeri retains on the lower teeth primitive characters typical of $M$. thorali (presence of first premolars, structure of $\mathrm{p} 2$ ), but upper cheek teeth are already as in M. meles. Combination of morphotypes A2/B4 is noted in 51 specimens of recent $M$. meles ( $13 \%$ of the sample) and only in 5 specimens of $M$. anakuma (3\% of the sample), combination A4/B3 occurred in 16 specimens of $M$. meles ( $4 \%$ of the sample) and is absent completely in $M$. anakuma.

Thus, in Europe badgers at the end of the Pliocene and the very beginning of the Pleistocene (M. thorali, $M$. dimitrius) combine characters of $M$. meles and $M$. anakuma. Their upper P4 and M1 show anakuma-morphotypes. Later, in the late Early Pleistocene the badgers acquire meles-morphotypes ( $M$. hollitzeri), although registered combinations seldom occur in recent $M$. meles. We can assume that such changes of tooth characters suggest early beginning of divergence between $M$. meles and $M$. anakuma, that became independent species in the early Middle Pleistocene, i.e. co-evolved independent of each other for approximately 800000 years.

Our hypothesis is supported by paleontological data on fossil badgers of Asia. Theilhard de Chardin (1940: fig. 16) described $M$. chiai from Locality 18 in China, which is dated to the Late Pliocene (Sotnikova, 1989). In $M$. chiai there are no P1/p1, for the upper teeth morphotypical combinations A4/B1 and A4/B2 are noted. Such 
combination have been defined in 27 specimens of recent $M$. anakuma (16\% of the sample) and only in 4 skulls of $M$. meles ( $1 \%$ of the sample).

Incomplete skull of badger identified as Meles cf. leucurus is known from the Middle Pleistocene site of Choukoutien 1 in China (Pei, 1934: fig. 19). Its morphotypes A2/B2 are typical of recent $M$. anakuma. Numerous findings from the Late Pleistocene localities in China (Zdansky, 1925: taf. 2, fig. 1), Primorskii Territory in Russia (Alekseeva, 1984), and in Japan (Shikama, 1949) also correspond to M. anakuma by morphotypical characters. The given data show that all known fossil badgers from Central and Eastern Asia possess anaku$m a$-morphotypes on the upper cheek teeth. Badger that was not different from the recent $M$. anakuma inhabited there since the Middle Pleistocene.

Paleontological material permits regarding anaku$m a$-morphotypes as plesiomorphic for badgers of the genus Meles, whereas meles-morphotypes are apomorphic. Rabeder (1976: Abb. 32) represented a scheme of phylogenetic relationships between representatives of the subfamily Melinae based on teeth characters. According to that scheme upper M1 of Meles terminate the morphological series of their transformation that began in more archaicMelodon Zdansky, 1924 andParataxidea Zdansky, 1924 from the Late Miocene and Early Pliocene of Asia. Anakuma-morphotypes are closer to the initial level of that series than meles-morphotypes.

\section{Conclusion}

Analysis of size and morphotypical variation of cheek teeth of Eurasian badgers revealed two geographical groups "western" and "eastern". Following the opinion of Baryshnikov \& Potapova (1990), we acknowledge them as separate species $M$. meles and $M$. anakuma, which also differ in pattern of head "mask" and baculum structure.

Both species of Eurasian badgers have mosaic of states of teeth characters. M. meles is characterized by the presence of first premolars P1/p1, large p2 with two roots (plesiomorphic characters), but meles-morphotypes in upper P4 and M1 (apomorphic characters). On the contrary in $M$. anakuma the first molars $\mathrm{P} 1 / \mathrm{p} 1$ as a rule are absent, p2 is small with one root (apomorphic characters), but upper teeth have anakuma-morphotypes (plesiomorphic characters). Different directions of dentition specialization support hypothesis of species ranks of European and Asian badgers, each of those having its own evolutionary fate.

The following scenario of speciation in Eurasian badgers may be proposed based on the assumption that their ancestor was $M$. thorali that had Palearctic distribution in the Late Pliocene. In the Early Pleistocene divergence of marginal populations began, probably as a result of separation of West European and East Asian parts of the range. Such separation (disconnection of the distribution range) could have been the result of mountain glaciation, transgression of the Caspian Sea, landscape rear- rangements in the glacial epoch, and other paleogeographic factors. This led to formation of two allopatric species in the Middle Pleistocene; M. meles was formed in Europe, M. anakuma in Central and Eastern Asia.

M. anakuma throughout its history was spread over the major part of continental Asia and in the Late Pleistocene invaded Japanese Islands. There were no essential changes in its distribution range, therefore the species has weak morphotypical variation of cheek teeth.

M. meles, which originated in Western Europe and the Mediterranean Region, on the contrary shows large morphotypical variation. European populations are very similar, but they are notably different from badgers of Asia Minor and Fore-Asia, Transcaucasia and Tajikistan. The latter were evidently temporarily isolated from European badgers by the Greater Caucasus and Bosporus and Dardanelles, which prevented genetic information exchange. This may account for the fact why in animals from Fore-Asia morphotypes of the upper teeth are predominant rarely occurring in European specimens of $M$. meles. Moreover, in the region of contact with $M$. anaku$m a$, sympatric zone could have been formed, which may have favored their hybridization. The boundary between the species was in all probability dynamic and changed with the change of paleogeographic situation. In south of Uzbekistan both species of badgers were biotopically separated.M. meles occupies mountain biotopes, whereas $M$. anakuma inhabits plains and semideserts.

In the Late Pleistocene natural conditions in the Russian Plain and in the Urals were unfavorable for badgers, so that their fossil remains are extremely rare. M. meles became widely spread in Eastern Europe only in the post-glacial time and its boundary with $M$. anaku$m a$, now passing along the Volga River probably was not established until the Holocene.

ACKNOWLEDGEMENTS. We are grateful to Dr. I. Pavlinov (ZMMU), late Dr. A. Forstén (ZMUH), Drs. J. Englund and J. Stanczak (NHR), Dr. P. Jenkins (MNH), Dr. R. Angermann (MHUB), Dr. A. Nadachowski (ISEA), Dr. V. Eisenmann (MNHN), Dr. V. Vomero (MCZR), Dr. M. Zeder (SI), Dr. B. Stanley (FM), and Dr. C. Guérin (Lyon) for access to the museum collection under their care.

We are thankful to V. Vekhnik (Russia, Zhiguli Nature Reserve) for his help in collecting material and also to Dr. D. Logunov (UK, Manchester) and Dr. A.K. Hufthammer (Norway, Bergen) for their help in work on the literature.

The work was fulfilled using scientific collections of the ZIN and supported by the Ministry of Science and Technology of the Russian Federation (\# 99-03-16).

The study was supported by grants of the Russian Foundation for Basic Research \#\# 02-04-48607 and 01-05-65448 (AP). GB obtained financial support for his visit to the Natural History Museum in London from the Royal Society (UK).

\section{References}

Abramov A.V. 2001. [Notes on the taxonomy of the Siberian badgers (Mustelidae: Meles)] // Trudy Zoologicheskogo Instituta RAN. Vol.288. P.221-233 [in Russian with English summary]. 
Abramov A.V. 2002. Variation of the baculum structure of the Palaearctic badger (Carnivora, Mustelidae, Meles) // Russian Journal of Theriology. Vol.1. No.1. P.57-60.

Alekseeva E.V. 1984. [Materials to study of fossil badger from Primorskii Territory] // [Problems of Variability and Zoogeography of Mammals]. Vladivostok. P.103-125 [in Russian].

Allen G.M. 1938. The mammals of China and Mongolia. Part 1. New York: The American Museum of Natural History. $620 \mathrm{p}$.

Baryshnikov G.F. 2001. [Order Carnivora] // Aristov A.A. \& Baranova G.I. (eds.). [Mammals of Russia and Adjacent Territories. Carnivores and Pinnipeds]. Sankt-Peterburg: Rossiiskaya Akademiya Nauk. P.11-425. [in Russian].

Baryshnikov G.F. 2002. Local biochronology of Middle and Late Pleistocene mammals from the Caucasus // Russian Journal of Theriology. Vol.1. No.1. P.61-67.

Baryshnikov G.F. \& Potapova O.R. 1990. [Variability of the dental system in badgers (Meles, Carnivora) of the USSR fauna] // Zoologicheskii Zhurnal. Vol.69. No.9. P.84-97 [in Russian with English summary].

Belyanin V.N. 1981. [The mammals of the Zhiguli Nature Reserve] // Kaletskaya M.L. (ed.). [Ecological and Morphological Researches in the Reservations]. Moskva: Tsentralnaya Nauchno-Issledovatel'skaya Laboratoriya Okhotnichego Khozayistva i Zapovednikov. P.89-103 [in Russian].

Corbet G.B. 1978. The Mammals of the Palaearctic Region: a Taxonomic Review. London, Ithaca: Cornell University Press. 314 p.

Davison M.L. \& Jones L.E. (eds.). 1983. Special Issue: Multidimensional Scaling and its Applications // Applied Psychological Measurement. No.7. P.373-514.

Degerbøl M. 1933. Danmarks pattedyr I fortiden I sammenligning med recente former // Videnskabelige Meddelelser fra dansk naturhistorisk Forening, Kobenhavn. Bd.96. P.357-641.

Ellerman J.R. \& Morrison-Scott T.C.S. 1951. Checklist of Palaearctic and Indian Mammals (1758 to 1946). London: Trustees of British Museum (Natural History). 810 p.

Evans J.D. 1968. Knossos Neolithic. Part II: Summary and conclusion // The Annual of the British School of Archaeology at Athens. Vol.63. P.267-276.

Festa E. 1914. Escursioni zoologiche del Dr. Enrico Festa nell' Isola di Rodi. XI. Mammiferi // Bollettino del Musei di Zoologia ed Anatomia comparata della R. Università di Torino. Vol.29. No.686. P.1-21.

Goodman L.A. \& Kruskal W.H. 1954. Measures of association for cross-classifications // Journal of the American Statistical Association. No.49. P.732-764.

Heptner V.G. 1968. [Some theoretical aspects of the appearance and distribution of Palearctic mammals. Two views on geographical variation] // Sbornik Trudov Zoologicheskogo Muzeya Moskovskogo Gosudarstvennogo Universiteta Vol.10. P.3-36 [in Russian].

Heptner V.G., Naumov N.P., Yurgenson P.B., Sludskii A.A., Chirkova A.F. \& Bannikov A.G. 1967. [Mammals of the Soviet Union. Vol.2. Part 1. Sea Cows and Carnivores]. Moskva: Vysshaya Shkola. 1004 p. [in Russian].

Hysing-Dahl Ch. 1954. Den norske grevling Meles meles (L.) // Naturvitenskapelig rekke, Bergen. No.16. P.1-55.
James F.C. \& McCulloch Ch.E. 1990. Multivariate analysis in ecology and systematics: panacea or Pandora's box? // Annual Review of Ecology and Systematics. Vol.21. P.129-166.

Jennrich R.I. 1977. Stepwise discriminant analysis // Enslein K., Ralston A. \& Wilf H.S. (eds.). Statistical Methods for Digital Computers. New York: Wiley. P.75-95.

Kamei T. 1981. Faunal succession of Pleistocene mammals in the Japanese Islands: an aspect // Quartärpaläontologie. Bd.4. P.165-174.

Kastschenko N.F. 1902. [About sandy badger (Meles arenarius Satunin) and about the Siberian races of badger] // Ezhegodnik Zoologicheskogo Muzeya Imperatorskoi Akademii Nauk. Vol.6 [for 1901]. No.4. P.609-613 [in Russian].

Koufos G. 1992. The Pleistocene carnivores of the Mygdonia basin (Macedonia, Greece) // Annales de Paleontologie (Vertébrés - Invertébrés). Vol.78. Fasc.4. P.205-257.

Kruskal J.B. 1964. Multidimensional scaling by optimizing goodness of fit to nonmetric hypothesis // Psychometrika. Vol.29. No.1. P.1-27.

Kurose N., Kaneko Y., Abramov A.V., Siriaroonrat B. \& Masuda R. 2001. Low genetic diversity in Japanese populations of the Eurasian badger Meles meles (Mustelidae, Carnivora) revealed by mitochondrial cytochrome $b$ gene sequences // Zoological Science. Vol.18. No.8. P.11451151.

Long C.A. \& Killingley C.A. 1983. The Badgers of the World. Springfield: Charles C.Thomas. 404 p.

Lüps P. \& Roper T. 1988. Tooth size in the European badger (Meles meles) with special reference to sexual dimorphism, diet and intraspecific aggression // Acta Theriologica. Vol.33. No.2. P.21-33.

Lüps P. \& Wandeler A. 1993. Gattung Meles Brisson, 1762 / / Stubbe M. \& Kraft F. (eds.). Handbuch der Säugetiere Europas. Bd.5. Teil.2. Wiesbaden: AULA-Verlag. S.855906.

Lynch J. 1994. Morphometric variation in the badger (Meles meles): clinal variation in cranial size and shape across Eurasia // Small Carnivore Conservation. No.10. P.6-7.

Lynch J., Whelan R., Fituri A.I. \& Hayden T.J. 1997. Craniometric variation in the Eurasian badger, Meles meles // Journal of Zoology, London. Vol.242. No.1. P.31-44.

Mein P. 1990. Updating of MN zones // Lindsay E.H., Fahlbusch V. \& Mein P. (eds.). European Neogene Mammal Chronology. New York: Plenum Press. P.73-90.

Neal E. 1948. The Badger. London: Collins. 158 p.

Ognev S.I. 1931. [The mammals of the Eastern Europe and Northern Asia]. T.2. Moskva-Leningrad: Gosizdat. 776 p. [in Russian].

Pei Wen-Chung. 1934. On the Carnivora from Locality 1 of Choukoutien // Palaeontologia Sinica, Series C. Vol.8. Fasc.1. P.1-166.

Petrov V.V. 1953. [The data on the intraspecific variability of badgers (genus Meles)] // Uchenye Zapiski Leningradskogo Pedagogicheskogo Instituta. T.7. P.149-205 [in Russian].

Puzachenko A.Yu. 2001. [Skull variability in the common mole rat Spalax microphthalmus (Spalacidae, Rodentia). 1. A method for analysis of data, nonage variability in males] // Zoologicheskii Zhurnal. T.80. No.3. P.343-357 
[in Russian with English summary].

Puzachenko Yu.G., Pridnya M.V., Martin V. \& Sankovski A.G. 1996. Representation of ecological niches of species for the mixed forest ecosystems of the Hubbard Brook Basin (White Mountains, New England, North America) // Russian Journal of Ecology. Vol.27. No.6. P.385.

Rabeder G. 1976. Die Carnivoren (Mammalia) aus dem Altpleistozän von Deutsch-Altenburg 2. Mit Beiträgen zur Systematik einiger Musteliden und Caniden // Beiträge zur Paläontologie der Österreich. Bd.1. S.5-119.

Satunin K.A. 1914. [Key to Mammals of the Russian Empire]. Vol.1. Tiflis: Tipografiya Kantselyarii Namestnika. 184 p. [in Russian].

Shepard B.N. 1962. The analysis of proximities: multidimensional scaling with unknown distance function // Psychometrika. Vol.27. No.2. P.125-140.

Shikama T. 1949. The Kuzuü ossuaries: geological and palaeontological studies of the limestone fissure deposits, in Kuzuü, Totigi Prefecture // The Sciences Reports of the Tohoku University, Sendai, Japan. Second Series: Geology. Vol.23. P.1-201.

Sneath P.H.A. \& Sokal R.R. 1973. Numerical Taxonomy. The principles and practice of numerical classification. San Francisco: W.H.Freeman. 573 p.

Sokal R.R. \& Rohlf F.J. 1981. Biometry. New York: W.H.Freeman \& Co. 837 p.

Sotnikova M.V. 1989. [Carnivora of the Pliocene and Early Pleistocene]// Trudy Geologicheskogo Instituta AN SSSR. T.440. P.1-125 [in Russian].
Steensma K. \& Reese D. 1996. The mustelines of Crete// Reese D. (ed.). Pleistocene and Holocene fauna of Crete and its first settlers. Madison, Wisconsin: Prehistory Press. P.159166. (Monograph in World Archaeology, No.28).

Stubbe M., Stubbe A., Ebersbach H., Samjaa R. \& Dorzraa O. 1998. Die Dachse (Melinae/Mustelidae) der Mongolei // Beiträge zur Jagt- und Wildforschung. Bd.23. S.257262.

Teilhard de Chardin P. 1940. The fossils from Locality 18 near Peking // Palaeontologia Sinica, Series C. No.124. P. $1-100$.

Viret J. 1950. Meles thorali n.sp. du loess villafranchien de Saint-Vallier (Drôme) // Eclogae geologicae helvetiae. Vol.43. No.2. P.274-287.

Wolsan M. 2001. Remains of Meles hollitzeri (Carnivora, Mustelidae) from the Lower Pleistocene site of Untermassfeld // Kahlke R.-D. (ed.). Das Pleistozän von Untermassfeld bei Meiningen (Thüringen). Teil 2. S.659-671. (Monographien des Römisch-Germanischen Zentralmuseums Mainz. Bd.40, 2).

Wozencraft W.C. 1993. Order Carnivora // Wilson D.E. \& Reeder D.A. (eds.). Mammal Species of the World: a Taxonomic and Geographic Reference. Washington, London: Smithsonian Institution Press (Second Edition). P.279-348.

Zdansky O. 1925. Quartäre carnivoren aus Nord-China // Palaeontologia Sinica, Series C. Vol.2. Fasc.2. P.1-30.

Zimmermann K. 1953. Die Carnivora von Kreta // Zeitschrift für Säugetierkunde. Bd.17. Hf.1. S.58-65. 